\title{
GENEReviews
}

Funded by the NIH · Developed at GeneTests (www.genetests.org), University of Washington, Seattle

\section{Congenital Central Hypoventilation Syndrome}

[Includes: Haddad Syndrome]

Debra E Weese-Mayer, MD

Professor of Pediatrics, Northwestern University Feinberg School of Medicine

Director, Center for Autonomic Medicine in Pediatrics (C.A.M.P.)

Children's Memorial Hospital

Chicago, IL

DWeese-Mayer@ChildrensMemorial.org

Mary L Marazita , PhD, FACMG

Professor, Department of Oral and Maxillofacial Surgery

Head, Division of Oral Biology

School of Dental Medicine

Professor, Department of Human Genetics

Graduate School of Public Health

Professor, Department of Psychiatry

School of Medicine

University of Pittsburgh

Pittsburgh, PA

marazita@sdmgenetics.pitt.edu

Elizabeth M Berry-Kravis, MD, PhD

Professor, Department of Pediatrics

Co-Director, Molecular Diagnostics Laboratory

Rush University Medical Center

Chicago, IL

elizabeth_m_berry-kravis@rush.edu

Initial Posting: January 28, 2004.

Last Revision: July 22, 2008.

\section{Summary}

Disease characteristics. Classic congenital central hypoventilation syndrome (CCHS) is characterized by adequate ventilation while the affected individual is awake and by hypoventilation with normal respiratory rates and shallow breathing during sleep; more severely affected individuals hypoventilate when both awake and asleep. Both phenotypes present in the newborn period. Children with CCHS often have physiologic and anatomic manifestations of a generalized autonomic nervous system dysfunction/dysregulation (ANSD); a subset have altered development of neural crest-derived structures (i.e., Hirschsprung disease) and tumors of neural crest origin including neuroblastoma, ganglioneuroma, and ganglioneuroblastoma. Recently, it has been recognized that some individuals with nocturnal alveolar hypoventilation, features of ANSD, and a polyalanine expansion mutation in PHOX2B characteristic of CCHS do not present until childhood or adulthood. Many individuals with CCHS who have been successfully ventilated are now in their 20s, suggesting the potential for a normal life span.

Diagnosis/testing. Diagnosis of CCHS is established by clinical findings and confirmatory molecular genetic testing. All individuals with the comprehensive CCHS phenotype are heterozygous for a mutation in the $P H O X 2 B$ gene. Whether mutations in genes other than $P H O X 2 B$ are pathogenic is unknown. The $P H O X 2 B$ polyalanine repeat expansion of 25-33 
repeats on the affected allele, accounting for $92 \%$ of cases, can be detected with a PCR-based assay. Sequence analysis of the entire coding region and intron-exon boundaries of $P H O X 2 B$ can detect mutations in the $8 \%$ of individuals with the CCHS phenotype who do not have an expansion mutation. Both tests are clinically available.

Management. Treatment of manifestations: tracheostomy and home ventilator for infants needing ventilatory support 24 hours per day; consider diaphragm pacing by phrenic nerve stimulation in ambulatory children requiring mechanical ventilation 24 hours per day in order to increase mobility and improve quality of life; consider nasal mask ventilation or negativepressure ventilation in cooperative children requiring ventilatory support only while sleeping but recognize the potential need for more aggressive ventilatory support during intercurrent illnesses; placement of a cardiac pacemaker for prolonged transient asystole; treatment of Hirschsprung disease in the usual manner; surgical removal of neuroblastoma, followed by chemotherapy if greater than stage 1 ; treatment of other tumors of neural crest origin by location and type. Prevention of secondary complications: Stable airway, optimal oxygenation and ventilation awake and asleep help to prevent respiratory compromise and optimize neurocognitive outcome. Surveillance: Screen infants with non-polyalanine $P H O X 2 B$ expansion mutations or the 20/27 to 20/33 genotype (i.e., 20 CGN repeats on one allele and 27-33 CGN repeats on the other allele) for Hirschsprung disease; screen infants with nonpolyalanine $P H O X 2 B$ expansion mutations or with the $20 / 31$ to $20 / 33$ genotype (i.e., 20 CGN repeats on one allele and 31,32, or $33 \mathrm{CGN}$ repeats on the other allele) for tumors of neural crest origin. Agents/circumstances to avoid: alcohol (respiratory depression). Testing of relatives at risk: Test parents of probands with the 20/25 genotype (i.e., 20 CGN repeats on one allele and $25 \mathrm{CGN}$ repeats on the other allele) for the PHOX2B mutation to determine their risk for later-onset CCHS. Other: Respiratory stimulants are typically ineffective in treating CCHS.

Genetic counseling. CCHS is inherited in an autosomal dominant manner. Most individuals with CCHS are heterozygous for de novo repeat expansions in $P H O X 2 B$. Some individuals diagnosed with CCHS have an affected parent. Approximately $5 \%$ of individuals with CCHS have an asymptomatic parent who has somatic mosaicism for a $P H O X 2 B$ mutation. Each child of an individual with a $P H O X 2 B$ mutation has a $50 \%$ chance of inheriting the mutation. The risk to the children of an individual who has somatic mosaicism for a $P H O X 2 B$ mutation of inheriting the mutation is $50 \%$ or lower. Genetic testing should be performed on both parents of a proband with CCHS. Physiologic respiratory testing and Holter recordings should be performed on any parent who has a $P H O X 2 B$ mutation (either mosaic or classic mutation). Prenatal testing for pregnancies at increased risk is possible if the causative mutation has been identified in an affected family member.

\section{Diagnosis Clinical Diagnosis}

The American Thoracic Society has issued a statement on the diagnosis of congenital central hypoventilation syndrome (CCHS) [Weese-Mayer et al 1999] and preparation of a revised statement is in process.

CCHS is diagnosed in individuals with the following:

- Hypoventilation with absent or negligible ventilatory sensitivity to hypercarbia and absent or variable ventilatory sensitivity to hypoxemia

- Generally adequate ventilation while awake, but hypoventilation with normal respiratory rate and shallow breathing (diminished tidal volume) during sleep OR 
- Hypoventilation both while awake and asleep

- Absent perception of asphyxia (i.e., absent behavioral awareness of hypercarbia and hypoxemia) and absent arousal

- No evidence of primary neuromuscular, lung, or cardiac disease or identifiable brain stem lesion that might account for the constellation of symptoms

\section{Molecular Genetic Testing}

GeneReviews designates a molecular genetic test as clinically available only if the test is listed in the GeneTests Laboratory Directory by at least one US CLIA-certified laboratory or a clinical laboratory outside the US. GeneTests does not independently verify information provided by laboratories and does not warrant any aspect of a laboratory's work. Listing in GeneTests does not imply that laboratories are in compliance with accreditation, licensure, or patent laws. Clinicians must communicate directly with the laboratories to verify information. - ED.

\section{Genes}

- $\quad$ PHOX2B. All individuals with the confirmed CCHS phenotype have a mutation in the $P H O X 2 B$ gene [Berry-Kravis et al 2006].

- Other genes. Twenty affected individuals with unique protein-altering mutations in other genes have been reported (see Molecular Genetics, Table 5). It is not clear if all individuals reported have been tested for $P H O X 2 B$ mutations or what role mutations in these other genes play in modifying the CCHS phenotype.

\section{Clinical uses}

- Confirmatory diagnostic testing

- Prenatal diagnosis

\section{Clinical testing}

- Targeted mutation analysis. $P H O X 2 B$ has two polyalanine repeat regions in exon 3 . The second polyalanine repeat region in exon 3 is the region of primary importance in CCHS. The polyalanine repeat can be made up of any one of four codon combinations - GCA, GCT, GCC, or GCG - as each one encodes the amino acid alanine. The term "GCN" has been used to designate these four codons.

Testing for presence of the $P H O X 2 B$ polyalanine repeat expansion mutation is accomplished with a PCR-based assay.

Ninety-two percent $(185 / 201)$ of individuals with CCHS are heterozygous for a polyalanine expansion mutation of 25-33 repeats (compared to the normal 20 repeats) [Berry-Kravis et al 2006].

Note: (1) Prior reports of $P H O X 2 B$ mutations in only $40 \%-97 \%$ of persons with CCHS reflect errors in PCR amplification of GC-rich regions [Amiel et al 2003; Sasaki et al 2003; Matera et al 2004; Trang, Dehan et al 2005; Trochet, O'Brien et al 2005] or sample misidentification at the laboratory of origin [Weese-Mayer, Berry-Kravis et al 2003; Berry-Kravis et al 2006]. (2) The number of reported cases of CCHS may be artificially elevated because more recent studies that typically include both the original datasets plus newly ascertained individuals may inadvertently count the same patient more than once. For example, it appears that a subset of the American cases reported by Trochet, O'Brien et al (2005) had already been reported in Weese-Mayer, Berry-Kravis et al (2003) [Weese-Mayer, Berry-Kravis, \& Marazita 2005]. 
- Sequence analysis. Eight percent (16/201) of individuals with CCHS have missense, nonsense, or frameshift mutations located at the $3^{\prime}$ end of $P H O X 2 B$ from the last six base pairs of exon 2 to the end of exon 3. Details of these mutations from all published reports are summarized in Berry-Kravis et al (2006).

Table 1 summarizes molecular genetic testing for this disorder.

Table 1. Molecular Genetic Testing Used in Congenital Central Hypoventilation Syndrome

\begin{tabular}{|c|c|c|c|}
\hline Test Method & Mutations Detected & Mutation Detection Frequency ${ }^{1}$ & Test Availability $^{2}$ \\
\hline Targeted mutation analysis & Polyalanine repeat expansion of $P H O X 2 B$ & $92 \%^{2}$ & Clinical \\
\hline Sequence analysis & PHOX2B non-polyalanine repeat sequence variants & $8 \%^{2}$ & Testin M \\
\hline
\end{tabular}

1. Proportion of affected individuals with a mutation(s) as classified by gene/locus, phenotype, population group, genetic mechanism, and/or test method

2. In individuals with the confirmed CCHS phenotype [Berry-Kravis et al 2006]

Interpretation of test results. For issues to consider in interpretation of sequence analysis results, click here.

\section{Testing Strategy}

Because more than $90 \%$ of individuals with CCHS have a $P H O X 2 B$ polyalanine expansion mutation and because $P H O X 2 B$ polyalanine expansion testing is a more sensitive test for detection of mosaicism, such testing should be performed first. Only if a $P H O X 2 B$ polyalanine expansion mutation is not found in an individual with the CCHS phenotype should sequencing of the entire coding region and intron-exon boundaries of the $P H O X 2 \mathrm{~B}$ gene be performed.

\section{Genetically Related (Allelic) Disorders}

No other phenotypes are known to be associated with mutations in $P H O X 2 B$.

Polymorphisms in intron 2 and in exon 3 have been reported in sudden infant death syndrome (SIDS) [Rand et al 2006] and Hirschsprung disease (HSCR) [Garcia-Barcelo et al 2003]. The significance of these polymorphisms in causation of these diseases is unknown at this time.

Schizophrenia and strabismus have been associated with the deletion variants in the PHOX2B polyalanine repeat tract observed in control populations without CCHS [Toyota et al 2004].

PHOX2B mutations have been reported in sporadic neuroblastomas [van Limpt et al 2004].

\section{Clinical Description}

\section{Natural History}

Congenital central hypoventilation syndrome (CCHS) represents the extreme manifestation of autonomic nervous system (ANS) dysfunction/dysregulation (ANSD), with a hallmark of disordered respiratory control [Weese-Mayer et al 1999].

Classic CCHS is characterized by adequate ventilation while the individual is awake but hypoventilation with normal respiratory rates and shallow breathing (diminished tidal volume) during sleep. More severely affected children hypoventilate when both awake and asleep [Weese-Mayer et al 1999]. Children who hypoventilate both when awake and when asleep typically present in the newborn period, as do the vast majority of children who hypoventilate only when asleep. The salient respiratory and cardiac findings of CCHS are summarized in Table 2. 
Table 2. Published Clinical Features of Congenital Central Hypoventilation Syndrome (CCHS)

\begin{tabular}{|c|c|c|}
\hline \multicolumn{2}{|r|}{ Clinical Feature } & References \\
\hline \multirow{3}{*}{ Respiratory } & Alveolar hypoventilation & Weese-Mayer et al 1999 \\
\hline & $\begin{array}{l}\text { Lack of normal ventilatory and arousal } \\
\text { responses to hypercarbia and hypoxemia }\end{array}$ & Weese-Mayer et al 1999 \\
\hline & Limited breath-to-breath variability & Weese-Mayer et al 1999; Weese-Mayer, Koch et al 2003 \\
\hline \multirow{4}{*}{ Cardiac } & Decreased heart rate beat-to-beat variability & Woo et al 1992; Ogawa et al 1993; Silvestri et al 2000; Trang, Girard et al 2005 \\
\hline & $\begin{array}{l}\text { Increased ratios of low frequency-band to } \\
\text { high frequency-band spectral power and } \\
\text { transient asystoles }\end{array}$ & Woo et al 1992, Ogawa et al 1993, Silvestri et al 2000 \\
\hline & Attenuated heart rate response to exercise & Silvestri et al 1995 \\
\hline & $\begin{array}{l}\text { Attenuated pulse arterial tonometry signal } \\
\text { magnitude followed sigh and with cold hand } \\
\text { pressor test }\end{array}$ & O'Brien et al 2005 \\
\hline
\end{tabular}

Children with CCHS often have physiologic and anatomic manifestations of generalized autonomic nervous system dysfunction (ANSD) (Table 3 and Table 4) including the following:

- Neurocristopathy (i.e., altered development of neural crest-derived structures) including Hirschsprung disease, congenital absence of parasympathetic intrinsic ganglion cells of the hindgut, in 16\%-20\% of individuals with CCHS. Hirschsprung disease typically presents in the newborn period, although it has been diagnosed later in infancy and early childhood.

- Tumors of neural crest origin including neuroblastoma, ganglioneuroma, and ganglioneuroblastoma, observed in 5\%-6\% of children with CCHS [Trochet, O'Brien et al 2005]. The tumors present at variable ages: neuroblastoma typically before age two years; ganglioneuromas later as incidental findings. Tumor-related deaths are uncommon.

- Symptoms of autonomic nervous system dysregulation (ANSD) [Marazita et al 2001, Weese-Mayer et al 2001]

- Physiologic evidence for ANSD [Faure et al 2002; O'Brien et al 2005; Trang et al 2003; Trang, Girard et al 2005]. Cardiovascular symptoms of ANSD include disturbances of heart rate and rhythm and blood pressure. Although baseline heart rate in persons with CCHS does not differ from controls, the relative increase above the mean heart rate at rest and with exercise is attenuated and heart rate variability is decreased [Silvestri et al 1995; Trang et al 2003; Trang, Girard et al 2005]. Children with CCHS exhibit an increased frequency of arrhythmia, primarily sinus bradycardia and transient asystole, with documented pauses as long as 6.5 seconds in CCHS vs. 1.4 seconds in controls [Silvestri et al 2000]. Children with CCHS exhibited lower blood pressure values during wakefulness and higher blood pressure values during sleep (vs. controls), indicating attenuation of the normal sleep-related blood pressure decrement [Trang et al 2003]. They also demonstrate a limited capacity to elevate their blood pressure on standing and head-up tilt positions, and do not demonstrate the normal standing-related blood pressure overshoot [Trang, Girard et al 2005]. 
Table 3. Physiologic Regulation of the Autonomic Nervous System

\begin{tabular}{|c|c|}
\hline Clinical Feature & References \\
\hline Severe constipation & Weese-Mayer et al 1993, Weese-Mayer et al 2001 \\
\hline $\begin{array}{c}\text { Esophageal dysmotility/dysphagia, decreased perception of discomfort, sporadic } \\
\text { profuse sweating, decreased basal body temperature }\end{array}$ & Weese-Mayer et al 1999, Faure et al 2002 \\
\hline Pupillary abnormalities & Weese-Mayer, Silvestri et al 1992; Goldberg \& Ludwig 1996 \\
\hline Decreased perception of anxiety & Pine et al 1994 \\
\hline Altered development of neural crest-derived structures & Berry-Kravis et al 2006; de Pontual et al 2006 \\
\hline Hirschsprung disease ( $\sim 16-20 \%$ of individuals) & Trochet, O'Brien et al 2005; Berry-Kravis et al 2006 \\
\hline $\begin{array}{c}\text { Tumors of neural crest origin (e.g., neuroblastoma, ganglioneuroblastoma, and } \\
\text { ganglioneuroma) }\end{array}$ & \\
\hline
\end{tabular}

* Including gastrointestinal, ophthalmologic, psychological, sudomotor systems

Table 4. Neuropathologic and Neuroimaging Findings

\begin{tabular}{|c|c|}
\hline Clinical Feature & References \\
\hline $\begin{array}{c}\text { Neuronal loss of the reticular nuclei and nearby cranial nerve nuclei (one } \\
\text { case) }\end{array}$ & Liu et al 1978 \\
\hline $\begin{array}{c}\text { Absent arcuate nucleus (one case) } \\
\text { Hypoxia-induced posterior thalamic, cerebellar, midbrain, and limbic } \\
\text { deficits }\end{array}$ & Folgering et al 1979 \\
\hline Multiple areas of white matter abnormality on brain MRI & Macey, Woo et al 2005 \\
\hline $\begin{array}{c}\text { Abnormal fMRI brain responses to cold pressor challenge, hypoxia, and } \\
\text { hyperoxia }\end{array}$ & Kacey, Macey et al 2005; Macey, Woo et al 2005; Woo et al 2005 \\
\hline
\end{tabular}

Updated and adapted from Marazita et al 2001 (Table 1)

Many successfully ventilated individuals with CCHS are now in their 20s, suggesting the potential for a normal life span. The cause of death in individuals with CCHS is related to suboptimal ventilatory support or involvement with substances that could affect judgment or ventilation [Chen et al 2006]. However, a recent report identified asystoles as another potential etiology of sudden death in CCHS [Gronli et al, in press] among children with prolonged r-r interval but who had not received a cardiac pacemaker.

A characteristic facial phenotype has been described in CCHS [Todd, Weinberg et al 2006]. The facies are generally shorter and flatter (evidenced by significantly decreased upper-face height, increased nasal tip protrusion, decreased nasolabial angle, decreased upper-lip height) and typically show an inferior inflection of the lateral segment of vermillion border on the upper lip. The significantly decreased facial index and decreased upper facial index (such that the face is short relative to its width) results in the characteristic box-shaped face. The results also suggest that males with CCHS are more significantly affected than females. Using five variables to characterize facies (upper-lip height, biocular width, upper facial height, nasal tip protrusion and the lip trait), $85.7 \%$ of individuals with CCHS and $82.2 \%$ of controls were correctly predicted.

Dermatoglyphic pattern type frequencies are altered in individuals with CCHS compared to controls. In particular, an increase of arches was observed in females, and an increase of ulnar loops in males. The largest differences were noted for the left hand and for individuals with both CCHS and Hirschsprung disease [Todd, Scott et al 2006].

Later-onset CCHS with PHOX2B mutations. Virtually all individuals with $P H O X 2 B$ mutations who present after the newborn period appear to have the 20/25 genotype (i.e., 20 
CGN repeats on one allele and 25 CGN repeats on the other allele), supporting the hypothesis that the 20/25 genotype has variable expressivity. These individuals have the characteristic alveolar hypoventilation during sleep and symptoms of autonomic nervous system (ANS) dysregulation; thus, these individuals who present at an older age still have CCHS.

Individuals reported with later-onset central hypoventilation and the $P H O X 2 B$ polyalanine expansion mutation:

- Two children [Matera et al 2004]

- One child [Trang et al 2004]

- A 35-year-old presenting with respiratory failure [Weese-Mayer, Berry-Kravis, \& Zhou 2005]

- Five children [Trochet, O'Brien et al 2005]

- Five adults presenting over age 21 years [Antic et al 2006]

\section{Genotype-Phenotype Correlations}

Association between the number of $P H O X 2 B$ polyalanine repeats and quantitative ANSD traits [i.e., number of ANSD symptoms and number of affected systems as described in WeeseMayer et al (2001) and Marazita et al (2001)] has been investigated [Weese-Mayer, BerryKravis et al 2003. Measured genotype analysis revealed a significant association between:

- $\quad P H O X 2 B$ polyalanine repeat mutation length and number of ANSD symptoms $(\mathrm{p}=0.021)$, but not number of ANSD-affected systems $(\mathrm{p}=0.129)$.

- The distribution of repeat mutation length and daily duration of required ventilatory support $(\mathrm{p}=0.003)$.

Matera et al (2004) reported a correlation between the size of the PHOX2B expanded allele and the severity of the respiratory phenotype and associated symptoms, though statistical analysis is not provided.

Individuals with the 20/27 genotype (i.e., 20 CGN repeats on one allele and 27 CGN repeats on the other allele) and greater polyalanine expansions are at greatest risk for Hirschsprung disease. Virtually all individuals with non-polyalanine repeat expansion mutations have Hirschsprung disease [Trochet, O'Brien et al 2005; Berry-Kravis et al 2006].

Individuals with non-polyalanine repeat expansion mutations have a greater risk of developing a tumor of neural crest origin than those with polyalanine expansions. Likewise, individuals with the greatest number of polyalanine repeats are also at an increased risk (albeit lower than the risk of those with non-polyalanine repeat expansion mutations) of developing a tumor of neural crest origin [Trochet, O'Brien et al 2005; Berry-Kravis et al 2006].

Evidence of a significant negative correlation between number of repeats and four anthropometric measures (measures get smaller for mandible breadth, nasolabial angle, lateral lip height, and mandible-face width index as the number of polyalanine repeats increase) has been observed [Todd, Weinberg et al 2006].

No significant association was found between the number of polyalanine repeats in PHOX2B and dermatoglyphic pattern frequencies [Todd, Scott et al 2006]. However, an increase in arches among girls and an increase in ulnar loops among boys was reported. 
A positive correlation between longest $r-r$ interval and genotype, and number of children for whom a cardiac pacemaker was recommended and genotype, was identified among individuals with $P H O X 2 B$ mutation-confirmed CCHS [Gronli et al, in press].

\section{Penetrance}

For the $P H O X 2 B$ expansion mutation, penetrance appears to be high. Amiel et al (2003), Sasaki et al (2003), Weese-Mayer, Berry-Kravis et al (2003), Matera et al (2004), and Berry-Kravis et al (2006) found no controls with the PHOX2B expansion mutation.

However, the recent identification of CCHS in adults and in young (but not infant) children, all with the 20/25 genotype (i.e., 20 CGN repeats on one allele and 25 CGN repeats on the other allele), indicates a reduced penetrance for this specific genotype in early childhood.

\section{Anticipation}

Limited data suggest that the polyalanine expansion in $P H O X 2 B$ is meiotically stable.

- In the ten instances in which the $P H O X 2 B$ expansion mutation was transmitted from a parent with CCHS to a child with CCHS [Weese-Mayer, Berry-Kravis et al 2003; Trochet, O'Brien et al 2005; Weese-Mayer, Berry-Kravis, \& Zhou 2005; Antic et al 2006], no change was observed in the number of repeats (i.e., parent and child had mutated alleles of the same size).

- In all 14 cases in which a parent of a child with CCHS was mosaic, the expansion mutation was transmitted unchanged from parent to child (i.e., the mosaic parent not manifesting CCHS and the proband child with CCHS had mutated alleles of the same size) [Weese-Mayer, Berry-Kravis et al 2003; Trochet, O'Brien et al 2005].

\section{Nomenclature}

The appropriate nomenclature for this disorder is congenital central hypoventilation syndrome (CCHS).

A literary misnomer, "Ondine's curse," has been used in past literature. In the story of Ondine, a German folk epic, [Sugar 1978], the nymph Ondine falls in love with a mortal. When the mortal is unfaithful to the nymph, the king of the nymphs places a curse on the mortal. The king's curse makes the mortal responsible for remembering to perform all bodily functions, even those that occur automatically such as breathing. When the mortal falls asleep, he "forgets" to breathe and dies. Because Ondine was not the one who cursed the mortal and children worldwide with CCHS do not forget to breathe, the term "Ondine's curse" is a misnomer and should be avoided.

Haddad syndrome refers to the co-occurrence of CCHS and Hirschsprung disease; the term is not widely used.

\section{Prevalence}

With the introduction of clinically available molecular genetic testing for $P H O X 2 B$ mutations, it has become apparent that CCHS is no longer as rare as previously considered. Current estimates are likely an underestimate.

Based on the authors' personal experience and the recent large published reports, the authors estimate that at least 500 cases of genetically confirmed CCHS are known at present. Each month four to ten new cases are being identified in the US through molecular genetic testing, with an increasing number of cases identified in each successive year since the clinical PHOX2B test became available [Weese-Mayer and Berry-Kravis, personal communication]. 
Increased awareness about the reduced penetrance of the 20/25 genotype (i.e., $20 \mathrm{CGN}$ repeats on one allele and 25 CGN repeats on the other allele) will likely lead to identification of more cases in the future.

\section{Differential Diagnosis}

For current information on availability of genetic testing for disorders included in this section, see GeneTests Laboratory Directory. - ED.

Children with congenital central hypoventilation syndrome (CCHS) typically present in the newborn period. Studies should be performed to rule out primary neuromuscular, lung, or cardiac disease or an identifiable brain stem lesion that could account for the constellation of symptoms characteristic for CCHS. Introduction of clinically available $P H O X 2 B$ genetic testing allows for distinction between CCHS and disorders to consider in the differential diagnosis such as severe prematurity [Bajaj et al 2005], identifiable brain stem findings that could (but do not) account for the hypoventilation [Bachetti et al 2006], asphyxia, infection, trauma, tumor, and infarction.

Because CCHS mimics many treatable and/or genetic diseases, the following disorders should be considered:

- X-linked myotubular myopathy (XLMTM). XLMTM is characterized by muscle weakness that ranges from severe to mild. Severe (classic) XLMTM presents with hypotonia and respiratory distress in newborns. Molecular testing of the MTM1 gene detects mutations in $80 \%-85 \%$ of affected individuals. Inheritance is X-linked recessive.

- Multiminicore disease (MmD). About $75 \%$ of individuals have classic MmD with onset that usually is congenital or occurs in early childhood with neonatal hypotonia, delayed motor development, and axial muscle weakness that lead to development of scoliosis and significant respiratory involvement. The diagnosis of $\mathrm{MmD}$ is based on the presence of multiple "minicores" visible on muscle biopsy oxidative stains. Mutations in SEPNI and RYR1 are known to cause MmD; other genes remain to be discovered.

- Congenital myasthenic syndrome (CMS). Congenital myasthenic syndromes are characterized by fatigable weakness involving ocular, bulbar, and limb muscles with onset at or shortly after birth. In some types of CMS, myasthenic symptoms may be mild, but sudden severe exacerbations of weakness or even sudden episodes of respiratory insufficiency may occur, precipitated by fever, infections, or excitement. If symptoms start in the neonatal period, respiratory insufficiency with sudden apnea and cyanosis may occur. CMS is limited to weakness of the skeletal muscles. Several genes encoding proteins expressed at the neuromuscular junction are currently known to be associated with CMS. Inheritance is autosomal recessive, or, less frequently, autosomal dominant.

- Altered airway or intrathoracic anatomy (diagnosis made with bronchoscopy and chest computerized tomography)

- Diaphragm dysfunction (diagnosis made with diaphragm fluoroscopy)

- Congenital cardiac disease (diagnosis made with echocardiogram)

- A structural hindbrain or brain stem abnormality (diagnosis made with magnetic resonance imaging of the brain and brain stem) 
- Mobius syndrome (diagnosis made with MRI of the brain and brain stem and neurologic examination)

- $\quad$ Specific metabolic diseases such as Leigh syndrome (See also Mitochondrial Disorders Overview), pyruvate dehydrogenase deficiency, and discrete carnitine deficiency (diagnosis with specific metabolic and/or molecular genetic testing)

Later-onset $P H O X 2 B$ mutation-confirmed CCHS needs to be distinguished from a disorder described more than 40 years ago termed "late-onset central hypoventilation with obesity and hypothalamic dysfunction." In 2000,Katz et al summarized the ten published case reports and described one additional patient. A group of 15 children with this syndrome who had findings that clearly distinguish it from CCHS was recently reported [Ize-Ludlow et al 2007]. To improve early identification of these special children who present with rapid weight gain (15-20 pounds) between ages three and ten years, Ize-Ludlow et al propose a new name for the syndrome: rapid-onset obesity with hypothalamic dysfunction, hypoventilation, and autonomic dysregulation (ROHHAD). Ize-Ludlow et al definitively demonstrated that children with ROHHAD do not have mutations in the PHOX2B gene, thereby distinguishing ROHHAD from CCHS genetically as well as phenotypically.

CCHS needs to be considered in individuals who do not have the characteristic CCHS phenotype, including: individuals with apparent life-threatening events and cyanosis during sleep, unexplained seizures, respiratory depression after anti-seizure medication, sedation, or anesthesia, unexplained neurocognitive delay with any history of prior cyanosis, unexplained nocturnal hypercarbia and hypoxemia, seeming unresponsiveness to conditions of apparent hypercarbia or hypoxemia (prolonged underwater swimming, pneumonia); and infants and children who die suddenly and unexpectedly (SIDS and sudden unexplained death of childhood [SUDC]). Because it is anticipated that a growing number of children and adults presenting with symptoms compatible with a mild version of CCHS will be found to be heterozygous for a $P H O X 2 B$ mutation, a differential diagnosis as thorough as that considered in infancy should be applied.

\section{Management}

\section{Evaluations Following Initial Diagnosis}

To establish the extent of disease in an individual diagnosed with congenital central hypoventilation syndrome (CCHS):

- Assessment in a pediatric respiratory physiology laboratory of spontaneous breathing awake and asleep including, at a minimum, tidal volume, respiratory inductance plethysmography of the chest and abdomen, hemoglobin saturation with pulse waveform, end-tidal carbon dioxide, and electrocardiogram and evaluation of the awake and asleep response of tidal volume and respiratory frequency to hypercarbia and hypoxemia

- 72-hour Holter recording to assess for transient asystoles and prolonged corrected QT interval (QTc)

- Ophthalmologic examination (i.e., careful pupillary assessment) to assess for autonomic ophthalmologic abnormality

- Echocardiogram to assess for changes consistent with cor pulmonale

- Neurocognitive assessment to determine baseline function 


\section{Treatment of Manifestations}

Ventilatory support. For each of the options described below, the goal is to match the affected individual with the technology optimal for her/his life style needs.

Typically, the infant needing ventilatory support 24 hours per day requires a tracheostomy and use of a home ventilator.

As children who require ventilatory support become ambulatory, diaphragm pacing by phrenic nerve stimulation can be considered to allow for increased mobility and improved quality of life. Diaphragm pacing is not typically recommended for the young child who requires only nighttime ventilatory support because the benefits do not outweigh the risks; however, for older adolescents and young adults, this could be an appropriate consideration.

- Diaphragm pacers for the active child with CCHS should be implanted in the chest [Weese-Mayer et al 1996, Shaul et al 2002].

- Older infants and toddlers with a diaphragm pacer may use a Passy-Muir one-way speaking valve while awake, allowing for vocalization and use of the upper airway on exhalation.

- Children with diaphragm pacers may be assessed for capping of the tracheostomy tube while awake, thereby allowing for inspiration and exhalation via the upper airway; tracheostomy is still required for mechanical ventilation during sleep.

- Although not yet accomplished, the older child with an entirely normal airway may be able to eliminate the need for a tracheostomy by relying on diaphragm pacing while awake and on nasal mask ventilation while asleep; however, such a child may require interim endotracheal intubation to allow for optimal oxygenation and ventilation during an illness requiring more aggressive ventilatory management.

Cooperative children with CCHS who consistently require ventilatory support only while sleeping may be candidates for non-invasive support with either nasal mask ventilation or negative-pressure ventilation. If successful, tracheal decannulation can be considered (with the caveat that in the event of severe illness, interim endotracheal intubation may be required). However, the child who normally requires ventilatory support during sleep only may, during an intercurrent illness, require artificial ventilation both awake and asleep.

Cardiac. Prolonged transient asystoles may present as syncope and/or staring spells, and may be of such significant duration as to warrant placement of a cardiac pacemaker for management [Silvestri et al 2000].

Hirschsprung disease. (See Hirschsprung Disease Overview.)

Tumors of neural crest origin. Neuroblastomas are removed surgically and followed by chemotherapy if they have advanced beyond stage 1. Other tumors of neural crest origin are treated individually by location and type.

\section{Prevention of Secondary Complications}

It is essential that individuals with CCHS be managed conservatively, with a stable airway and optimal oxygenation and ventilation awake and asleep in order to optimize neurocognitive outcome, careful follow-up with physiologic studies, home monitoring with a pulse oximeter and end-tidal carbon dioxide monitor, and highly skilled home care by a registered nurse.

Mask ventilation in the infant and young child is strongly discouraged as the potential for doing harm with facial deformation is an important consideration, necessitating midface 
advancement in the teen years. Also, mask ventilation is not adequately stable as a lifesustaining support, with risk for repeated hypoxemia and neurocognitive compromise in the infant and young child. If mask ventilation is used, close longitudinal follow-up by specialists with craniofacial and dental expertise is essential.

\section{Surveillance}

Infants with non-polyalanine expansion mutations in $P H O X 2 B$ should be screened for Hirschsprung disease and tumors of neural crest origin. Individuals with the 20/31 to 20/33 genotype (i.e., $20 \mathrm{CGN}$ repeats on one allele and 31, 32, or $33 \mathrm{CGN}$ repeats on the other allele) should be screened for tumors of neural crest origin in infancy and childhood.

\section{Agents/Circumstances to Avoid}

Alcohol is a serious respiratory depressant [Chen et al 2006].

\section{Testing of Relatives at Risk}

Parents of probands with the 20/25 genotype (i.e., 20 CGN repeats on one allele and 25 CGN repeats on the other allele) should be tested for the PHOX2B mutation to confirm they are not at risk for the later-onset form of CCHS.

See Genetic Counseling for issues related to testing of at-risk relatives for genetic counseling purposes.

\section{Therapies Under Investigation}

Search ClinicalTrials.gov for access to information on clinical studies for a wide range of diseases and conditions. Note: There may not be clinical trials for this disorder.

\section{Other}

Respiratory stimulants are typically ineffective in treating CCHS.

When available for infants and children, comprehensive autonomic testing of all organ systems regulated by the ANS will be an important means of evaluating individuals with CCHS.

Genetics clinics, staffed by genetics professionals, provide information for individuals and families regarding the natural history, treatment, mode of inheritance, and genetic risks to other family members as well as information about available consumer-oriented resources. See the GeneTests Clinic Directory.

Support groups have been established for individuals and families to provide information, support, and contact with other affected individuals. The Resources section may include disease-specific and/or umbrella support organizations.

\section{Genetic Counseling}

Genetic counseling is the process of providing individuals and families with information on the nature, inheritance, and implications of genetic disorders to help them make informed medical and personal decisions. The following section deals with genetic risk assessment and the use of family history and genetic testing to clarify genetic status for family members. This section is not meant to address all personal, cultural, or ethical issues that individuals may face or to substitute for consultation with a genetics professional. To find a genetics or prenatal diagnosis clinic, see the GeneTests Clinic Directory. - ED. 


\section{Mode of Inheritance}

CCHS is inherited in an autosomal dominant manner [Weese-Mayer, Berry-Kravis et al 2003].

\section{Risk to Family Members}

\section{Parents of a proband}

- Most individuals with CCHS are heterozygous for de novo mutations in PHOX2B.

- Some individuals diagnosed with CCHS have an affected parent known to have CCHS [Weese-Mayer, Berry-Kravis et al 2003; Trochet, O'Brien et al 2005; Antic et al 2006].

- Approximately 5\% of individuals with CCHS have an asymptomatic parent (nonCCHS) who has somatic mosaicism for a $P H O X 2 B$ mutation [Weese-Mayer, BerryKravis et al 2003; Trochet, O'Brien et al 2005; Berry-Kravis et al 2006]. Parents with mosacism should have comprehensive physiologic assessment to determine features of the CCHS phenotype.

- Recommendations for the evaluation of parents of a proband with a presumed de novo mutation include testing of both parents for the PHOX2B mutation.

\section{Sibs of a proband}

- The risk to the sibs of the proband depends upon the genetic status of the proband's parents.

- If a parent of the proband is affected, the risk to the sibs is $50 \%$.

- If a parent of the proband has somatic mosaicism for the $P H O X 2 B$ polyalanine repeat expansion, the recurrence risk to the sibs of the proband is $50 \%$ or lower.

- When the parents are clinically unaffected, a risk to the sibs of a proband may still be present since somatic mosaicism in asymptomatic parents has been reported and germline mosaicism, although not yet reported, remains a possibility [Weese-Mayer, Berry-Kravis et al 2003].

Offspring of a proband. Each child of an individual with CCHS has a $50 \%$ chance of inheriting the mutation.

Other family members. The risk to other family members depends upon the status of the proband's parents. If a parent is found to be affected, his or her family members are at risk.

\section{Related Genetic Counseling Issues}

Family planning. The optimal time for determination of genetic risk and discussion of the availability of prenatal testing is before pregnancy.

DNA banking. DNA banking is the storage of DNA (typically extracted from white blood cells) for possible future use. Because it is likely that testing methodology and our understanding of genes, mutations, and diseases will improve in the future, consideration should be given to banking DNA of affected individuals. DNA banking is particularly relevant in situations in which the sensitivity of currently available testing is less than $100 \%$. See DNA Banking for a list of laboratories offering this service. 


\section{Prenatal Testing}

Prenatal diagnosis for pregnancies at increased risk is possible by analysis of DNA extracted from fetal cells obtained by amniocentesis usually performed at about 15-18 weeks' gestation or chorionic villus sampling (CVS) at about ten to 12 weeks' gestation. The disease-causing allele of an affected family member must be identified before prenatal testing can be performed.

Note: Gestational age is expressed as menstrual weeks calculated either from the first day of the last normal menstrual period or by ultrasound measurements.

Preimplantation genetic diagnosis (PGD) may be available for families in which the diseasecausing mutation has been identified in an affected family member. For laboratories offering PGD, see Testing.

\section{Molecular Genetics}

Information in the Molecular Genetics tables may differ from that in the text; tables may contain more recent information. - ED.

Table A. Molecular Genetics of Congenital Central Hypoventilation Syndrome

\begin{tabular}{|c|c|c|}
\hline Gene Symbol & Chromosomal Locus & Protein Name \\
\hline PHOX2B & $4 \mathrm{p} 12$ & Paired mesoderm homeobox protein 2B \\
\hline
\end{tabular}

Data are compiled from the following standard references: gene symbol from HUGO; chromosomal locus, locus name, critical region, complementation group from OMIM; protein name from Swiss-Prot.

Table B. OMIM Entries for Congenital Central Hypoventilation Syndrome

\begin{tabular}{|l|l|}
\hline 209880 & AUTONOMIC CONTROL, CONGENITAL FAILURE OF \\
\hline 603851 & PAIRED-LIKE HOMEOBOX 2B; PHOX2B \\
\hline
\end{tabular}

Table C. Genomic Databases for Congenital Central Hypoventilation Syndrome

\begin{tabular}{|c|c|c|c|c|c|}
\hline Gene Symbol & Entrez Gene & HGMD & GeneCards & GDB & GenAtlas \\
\hline PHOX2B & 8929 (MIM No. 603851) & PHOX2B & PHOX2B & 9957899 & PHOX2B \\
\hline
\end{tabular}

For a description of the genomic databases listed, click here.

Note: HGMD requires registration.

\section{Molecular Genetic Pathogenesis}

PHOX2B polyalanine expansion. $\mathrm{PHOX} 2 \mathrm{~B}$ has two polyalanine repeat regions in exon 3 . The second polyalanine repeat region in exon 3 is the region of primary importance in CCHS. The polyalanine repeat can be made up of any one of four codon combinations - GCA, GCT, GCC, or GCG - as each one encodes the amino acid alanine. The term "GCN" has been used to designate these four codons.

Mutations that result in polyalanine expansion have been described as a cause of disease in a number of homeodomain- and non-homeodomain-containing transcription factors including:

- HOXD13 (synpolydactyly)

- HOXA13 (see Hand-Foot-Genital Syndrome)

- $R U N X 2$ (See Cleidocranial Dysplasia),

- $\quad$ ZIC2 (see Holoprosencephaly Overview) [Goodman \& Scambler 2001]. 
There is precedent for polyalanine repeat tract expansion in a homeobox gene as a cause of neurologic disease resulting from presumed failure of specification and/or migration of a specific neuronal cell type. The Aristaless-related homeobox gene $(A R X)$ has been associated with XLAG (X-linked lissencephaly and ambiguous genitalia) [Kitamura et al 2002], X-linked mental retardation [Bienvenu et al 2002], X-linked and sporadic infantile spasms, and other developmental disorders with mental retardation and epilepsy [Stromme et al 2002]. This ARX gene contains a polyalanine tract that is expanded in some affected individuals, particularly those with infantile spasms or myoclonic epilepsy. Other affected individuals have missense or truncating mutations that likely result in loss of function.

Mice with mutations in Arx show aberrant differentiation and migration of GABA-ergic neurons in neocortex [Kitamura et al 2002]. Given the expression patterns of PHOX2B in central autonomic structures and peripheral neural crest derivatives and the wide range of ANS dysfunction seen in CCHS, it seems likely that a similar mechanism of aberrant differentiation and/or migration of central and peripheral noradrenergic sympathetic and parasympathetic neurons results from the polyalanine tract expansion in $P H O X 2 B$.

Role of $P H O X 2 B$ in embryogenesis. $P H O X 2 B$ has an early embryologic action as a transcriptional activator in promotion of pan-neuronal differentiation including upregulation of proneural gene and $\mathrm{MASH} 1$ expression and expression of motoneural differentiation [Dubreuil et al 2002]. $P H O X 2 B$ appears to be switched on just prior to the last mitosis [Dubreuil et al 2002]. $P H O X 2 B$ has a separate role by a different pathway wherein it represses expression of inhibitors of neurogenesis [Dubreuil et al 2002]. $P H O X 2 B$ is required to express tyrosine hydroxylase (see GTP Cyclohydrolase 1-Deficient Dopa-Responsive Dystonia), dopamine beta hydroxylase (see Dopamine Beta-Hydroxylase Deficiency) [Lo et al 1999], and RET (see Multiple Endocrine Neoplasia Type 2 and Hirschsprung Disease Overview), and to maintain MASH1, thereby indicating regulation of $P H O X 2 B$ over the noradrenergic phenotype in vertebrates [Pattyn et al 1999]. These roles of $P H O X 2 B$ early in the embryologic origin of the ANS with a role in determining the fate of early neuronal cells and a role in disinhibition of neuron differentiation could account for the seeming imbalance in the sympathetic and parasympathetic nervous system and relative dysfunction in the enteric nervous system in children with CCHS. Extensive studies by Pattyn et al $(1997,1999)$ indicate an early expression pattern of $P H O X 2 B$ in rhombencephalon, suggesting a link to early patterning events with later neurogenesis in the hindbrain.

In the mouse, phox $2 b$ is expressed in the neonatal CNS, specifically in the area postrema, nucleus tractus solitarius, dorsal motor nucleus of the vagus, nucleus ambiguus, ventral surface of medulla, locus coeruleus (until embryonic day 11.5), and cranial nerves III (oculomotor), IV (trochlear), Vll (facial), IX (glossopharyngeal), and X (vagus). Until mid-gestation in the mouse, phox $2 b$ is expressed in the Vth (trigeminal) cranial nerve. In the mouse peripheral nervous system, phox $2 b$ is expressed in the distal VIIth, IXth, and Xth cranial sensory ganglia from embryonic day 9.5 and in all autonomic nervous system ganglia as early as formed, until at least mid-gestation. Finally, by embryonic day 9-9.5, the phox 2 b protein is detected in enteric neuroblasts invading the foregut mesenchyme. It is expressed in the esophagus, small intestine, and large intestine [Pattyn et al 1997, 1999] and in all undifferentiated neural crest-derived cells in the gut with a rostro-caudal gradient [Young et al 1999]. In the phox $2 b$ knockout mouse, the gut is devoid of enteric neurons and even the neural crest-derived cells that are found in the foregut at E10.5 do not survive or migrate further [Young et al 1999].

The phenotypic findings of CCHS (symptoms of ANSD in the respiratory control system, cardiovascular system, ophthalmologic system, neurologic system, and gastrointestinal system) follow logically from the embryologic distribution of $P H O X 2 B$. It remains unclear how the distribution and actions of $P H O X 2 B$ account for involvement of other systems often 
included in the ANSD profile of the child with CCHS, including the sudomotor, psychological, and renal systems.

Mutations in other genes have been identified in persons with CCHS (Table 5); their significance is not known.

Table 5. Other Genes with Mutations Reported in Individuals with CCHS With or Without a PHOX2B Polyalanine Expansion

\begin{tabular}{|c|c|c|c|}
\hline Gene Symbol & $\begin{array}{c}\text { \# Individuals } \\
\text { Reported with a } \\
\text { Mutation in This } \\
\text { Gene }\end{array}$ & $\begin{array}{c}\text { \# Individuals with Specified Gene } \\
\text { AND PHOX2B Polyalanine } \\
\text { Expansion }\end{array}$ & Reference \\
\hline RET & 8 & 3 & Amiel et al 1998, Sakai et al 1998, Sakai et al 2001, Fitze et al \\
2003, Sasaki et al 2003
\end{tabular}

The $P H O X 2 B$ repeat expansion mutation segregated with CCHS in families from which parental samples were analyzed, while the $R E T, G D N F, B D N F$, and $H A S H 1$ mutations did not. It is unknown to the authors if all individuals with these mutations have been tested for PHOX2B mutations. Therefore, the role of mutations in genes other than PHOX2B in disease causation is unclear; they could be pathogenic or benign polymorphisms. See Weese-Mayer, Berry-Kravis, \& Marazita (2005) for a complete discussion.

Normal allelic variants: $P H O X 2 B$ has a "GCN" repeat in exon 3 that is made up of any one of four codon combinations - GCA, GCT, GCC, or GCG - that each encodes the amino acid alanine. (The term "GCN" has been used to designate these four codons). A 20-repeat length is normal; benign variants of nine, 13, 14, and 15 repeats have been reported [Amiel et al 2003; Weese-Mayer, Berry-Kravis et al 2003; Toyota et al 2004]

Pathologic allelic variants: GCN tract of 25-33 repeats (For more information, see Genomic Databases table above.) Thirty-four individuals with a non-polyalanine expansion mutation have been identified thus far [Amiel et al 2003; Sasaki et al 2003; Weese-Mayer, Berry-Kravis et al 2003; Matera et al 2004; Trochet, Hong et al 2005; Berry-Kravis et al 2006].

Normal gene product: $\mathrm{PHOX} 2 \mathrm{~B}$ encodes a highly conserved homeobox domain transcription factor (314 amino acids), with two short and stable polyalanine repeats of nine and 20 residues encoded by the GCN repeat in exon 3 [Amiel et al 2003].

Abnormal gene product: Triplet repeat disorders can cause disease through either gain-offunction or loss-of-function mechanisms. Lack of a CCHS phenotype in mice haploinsufficient for Phox $2 b$ (but with dilated pupils and atrophy of the ciliary ganglion) [Cross et al 2004], combined with the finding that nearly all individuals with CCHS have mutations that alter the protein downstream from the homeodomain [Amiel et al 2003; Sasaki et al 2003; WeeseMayer, Berry-Kravis et al 2003; Matera et al 2004], suggest that mutations causing CCHS 
result in a change in function rather than simply reducing the amount of the $P H O X 2 B$ protein. Since paired-homeodomain proteins such as $P H O X 2 B$ bind to their target sites on DNA as dimers, $P H O X 2 B$ mutants with the binding site intact would have the potential to act in a dominant-negative manner, interfering with the function of the wild-type protein. Several lines of evidence support a dominant-negative mechanism for PHOX2B mutations in CCHS:

- Other polyalanine repeat mutations in homeodomain proteins associated with human disease are thought to act in a dominant-negative fashion (syndactyly and HOXD13 [Goodman et al 1997]; hand-foot-genital syndrome and HOXA13 [Utsch et al 2002]).

- Transcriptional activity of $P H O X 2 B$ deletion variants (deleted for 1- to 13-alanine residues) was decreased to roughly $50 \%-70 \%$ of wild-type activity, while a five-repeat expansion reduced transcriptional activity to about $20 \%$ of wild type [Toyota et al 2004].

- Individuals with deletion variants including nine, 13, 14, and 15 alanine repeats as well as an expansion with 22 repeats have been described as population variants without CCHS, while individuals with five- or more -repeat expansions uniformly have CCHS [Weese-Mayer, Berry-Kravis et al 2003; Amiel et al 2003; Toyota et al 2004].

- Weese-Mayer, Berry-Kravis et al (2003) and Matera et al (2004) have shown a correlation between polyalanine repeat length in CCHS and severity of autonomic symptoms.

Both polyalanine repeat mutations and non-polyalanine repeat mutations in $P H O X 2 B$ impair transcriptional function; transcriptional impairment increases with mutation size for polyalanine repeat mutations [Matera et al 2004, Bachetti et al 2005]. For non-polyalanine repeat mutations, the least impairment of transcriptional function, comparable to activity from the smallest (5-repeat) polyalanine expansion, was seen with the 618delC mutation [Bachetti et al 2005], which results in a similarly mutated protein to the $577 \mathrm{delG}$ mutant, both -1 frameshifts occurring in the same area of the protein. This is consistent with incomplete penetrance with a small subset of the non-polyalanine mutations and the 20/25 genotype (i.e., 20 CGN repeats on one allele and 25 CGN repeats on the other allele). Thus, specific types and locations of mutations may be more prone to present with variable expressivity and reduced penetrance, based on a milder effect on $P H O X 2 B$-mediated transcription.

Given the data available from mouse models and humans with CCHS, it is likely that a threshold effect for $P H O X 2 B$ activity exists, below which the CCHS phenotype is manifest. Thus, loss of an allele is insufficient to cause disease, but activity is reduced below the disease threshold in individuals with a polyalanine expansion mutation or distal truncating mutation because of a dominant-negative effect on function of the wild-type protein, reducing $P H O X 2 B$ activity to less than $50 \%$.

\title{
Resources
}

GeneReviews provides information about selected national organizations and resources for the benefit of the reader. GeneReviews is not responsible for information provided by other organizations. -ED.

\author{
International Foundation for Functional Gastrointestinal Disorders (IFFGD) - \\ Pediatric \\ Phone: 888-964-2001 \\ Email: aanastas@iffgd.org \\ www.aboutkidsgi.org
}




\section{References}

Medical Genetic Searches: A specialized PubMed search designed for clinicians that is located on the PubMed Clinical Queries page. PubMed

\section{Published Statements and Policies Regarding Genetic Testing}

American Thoracic Society (1999) Position paper on the diagnosis and management of CCHS (Adobe ${ }^{\circledR}$ Acrobat Reader required)

\section{Literature Cited}

Amiel J, Laudier B, Attie-Bitach T, Trang H, de Pontual L, Gener B, Trochet D, Etchevers H, Ray P, Simonneau M, Vekemans M, Munnich A, Gaultier C, Lyonnet S. Polyalanine expansion and frameshift mutations of the paired-like homeobox gene PHOX2B in congenital central hypoventilation syndrome. Nat Genet. 2003;33:459-61. [PubMed: 12640453]

Amiel J, Salomon R, Attie T, Pelet A, Trang H, Mokhtari M, Gaultier C, Munnich A, Lyonnet S. Mutations of the RET-GDNF signaling pathway in Ondine's curse. Am J Hum Genet. 1998;62:7157. [PubMed: 9497256]

Antic NA, Malow BA, Lange N, McEvoy RD, Olson AL, Turkington P, Windisch W, Samuels M, Stevens CA, Berry-Kravis EM, Weese-Mayer DE. PHOX2B mutation-confirmed congenital central hypoventilation syndrome: presentation in adulthood. Am J Respir Crit Care Med. 2006;174:923-7. [PubMed: 16873766]

Bachetti T, Matera I, Borghini S, Di Duca M, Ravazzolo R, Ceccherini I. Distinct pathogenetic mechanisms for PHOX2B associated polyalanine expansions and frameshift mutations in congenital central hypoventilation syndrome. Hum Mol Genet. 2005;14:1815-24. [PubMed: 15888479]

Bachetti T, Robbiano A, Parodi S, Matera I, Merello E, Capra V, Baglietto MP, Rossi A, Ceccherini I, Ottonello G. Brainstem anomalies in two patients affected by congenital central hypoventilation syndrome. Am J Respir Crit Care Med. 2006;174:706-9. [PubMed: 16763219]

Bajaj R, Smith J, Trochet D, Pitkiin J, Ouvrier R, Graf N, Sillence D, Kluckow M. Congenital central hypoventilation syndrome and Hirschsprung's disease in an extremely preterm infant. Pediatrics. 2005;115:737-8. [PubMed: 15930201]

Berry-Kravis EM, Zhou L, Rand CM, Weese-Mayer DE. Congenital central hypoventilation syndrome: PHOX2B mutations and phenotype. Am J Respir Crit Care Med. 2006;174:1139-44. [PubMed: 16888290]

Bienvenu T, Poirier K, Friocourt G, Bahi N, Beaumont D, Fauchereau F, Ben Jeema L, Zemni R, Vinet MC, Francis F, Couvert P, Gomot M, Moraine C, van Bokhoven H, Kalscheuer V, Frints S, Gecz J, Ohzaki K, Chaabouni H, Fryns JP, Desportes V, Beldjord C, Chelly J. ARX, a novel Prd-classhomeobox gene highly expressed in the telencephalon, is mutated in X-linked mental retardation. Hum Mol Genet. 2002;11:981-91. [PubMed: 11971879]

Bolk S, Angrist M, Xie J, Yanagisawa M, Silvestri JM, Weese-Mayer DE, Chakravarti A. Endothelin-3 frameshift mutation in congenital central hypoventilation syndrome. Nat Genet. 1996;13:395-6. [PubMed: 8696331]

Chen ML, Turkel SB, Jacobson JR, Keens TG. Alcohol use in congenital central hypoventilation syndrome. Pediatr Pulmonol. 2006;41:283-5. [PubMed: 16429433]

Cross SH, Morgan JE, Pattyn A, West K, McKie L, Hart A, Thaung C, Brunet JF, Jackson IJ. Haploinsufficiency for Phox $2 \mathrm{~b}$ in mice causes dilated pupils and atrophy of the ciliary ganglion: mechanistic insights into human congenital central hypoventilation syndrome. Hum Mol Genet. 2004;13:1433-9. [PubMed: 15150159]

de Pontual L, Nepote V, Attie-Bitach T, Al Halabiah H, Trang H, Elghouzzi V, Levacher B, Benihoud K, Auge J, Faure C, Laudier B, Vekemans M, Munnich A, Perricaudet M, Guillemot F, Gaultier C, Lyonnet S, Simonneau M, Amiel J. Noradrenergic neuronal development is impaired by mutation of the proneural HASH-1 gene in congenital central hypoventilation syndrome (Ondine's curse). Hum Mol Genet. 2003;12:3173-80. [PubMed: 14532329] 
de Pontual L, Pelet A, Trochet D, Jaubert F, Espinosa-Parrilla Y, Munnich A, Brunet JF, Goridis C, Feingold J, Lyonnet S, Amiel J. Mutations of the RET gene in isolated and syndromic Hirschsprung's disease in human disclose major and modifier alleles at a single locus. J Med Genet. 2006;43:41923. [PubMed: 16443855]

Dubreuil V, Hirsch MR, Jouve C, Brunet JF, Goridis C. The role of Phox2b in synchronizing pan-neuronal and type-specific aspects of neurogenesis. Development. 2002;129:5241-53. [PubMed: 12399315]

Faure C, Viarme F, Cargill G, Navarro J, Gaultier C, Trang H. Abnormal esophageal motility in children with congenital central hypoventilation syndrome. Gastroenterology. 2002;122:1258-63. [PubMed: 11984512]

Fitze G, Paditz E, Schlafke M, Kuhlisch E, Roesner D, Schackert HK. Association of germline mutations and polymorphisms of the RET proto-oncogene with idiopathic congenital central hypoventilation syndrome in 33 patients. J Med Genet. 2003;40:E10. [PubMed: 12566528]

Folgering H, Kuyper F, Kille JF. Primary alveolar hypoventilation (Ondine's curse syndrome) in an infant without external arcuate nucleus. Case report. Bull Eur Physiopathol Respir. 1979;15:659-65. [PubMed: 497494]

Garcia-Barcelo M, Sham MH, Lui VC, Chen BL, Ott J, Tam PK. Association study of PHOX2B as a candidate gene for Hirschsprung's disease. Gut. 2003;52:563-7. [PubMed: 12631670]

Goldberg DS, Ludwig IH. Congenital central hypoventilation syndrome: ocular findings in 37 children. J Pediatr Ophthalmol Strabismus. 1996;33:175-80. [PubMed: 8771521]

Goodman FR, Mundlos S, Muragaki Y, Donnai D, Giovannucci-Uzielli ML, Lapi E, Majewski F, McGaughran J, McKeown C, Reardon W, Upton J, Winter RM, Olsen BR, Scambler PJ. Synpolydactyly phenotypes correlate with size of expansions in HOXD13 polyalanine tract. Proc Natl Acad Sci U S A. 1997;94:7458-63. [PubMed: 9207113]

Goodman FR, Scambler PJ. Human HOX gene mutations. Clin Genet. 2001;59:1-11. [PubMed: 11206481]

Gronli JO, Santucci BA, Leurgans SE, Berry-Kravis EM, Weese-Mayer DE. Congenital central hypoventilation syndrome: PHOX2B genotype determines risk for sudden death. Pediatr Pulmonol . in press [PubMed: 17606542]

Ize-Ludlow D, Gray J, Sperling MA, Berry-Kravis EM, Milunsky JM, Farooqi IS, Rand CM, WeeseMayer DE. Rapid onset obesity with hypothalamic dysfunction, hypoventilation, and autonomic dysregulation presenting in childhood. Pediatrics. 2007;120:e179-88. [PubMed: 17606542]

Katz ES, McGrath S, Marcus CL. Late-onset central hypoventilation with hypothalamic dysfunction: a distinct clinical syndrome. Pediatr Pulmonol. 2000;29:62-8. [PubMed: 10613788]

Kitamura K, Yanazawa M, Sugiyama N, Miura H, Iizuka-Kogo A, Kusaka M, Omichi K, Suzuki R, KatoFukui Y, Kamiirisa K, Matsuo M, Kamijo S, Kasahara M, Yoshioka H, Ogata T, Fukuda T, Kondo I, Kato M, Dobyns WB, Yokoyama M, Morohashi K. Mutation of ARX causes abnormal development of forebrain and testes in mice and X-linked lissencephaly with abnormal genitalia in humans. Nat Genet. 2002;32:359-69. [PubMed: 12379852]

Kumar R, Macey PM, Woo MA, Alger JR, Keens TG, Harper RM. Neuroanatomic deficits in congenital central hypoventilation syndrome. J Comp Neurol. 2005;487:361-71. [PubMed: 15906312]

Liu HM, Loew JM, Hunt CE. Congenital central hypoventilation syndrome: a pathologic study of the neuromuscular system. Neurology. 1978;28:1013-19. [PubMed: 570656]

Lo L, Morin X, Brunet JF, Anderson DJ. Specification of neurotransmitter identity by Phox2 proteins in neural crest stem cells. Neuron. 1999;22:693-705. [PubMed: 10230790]

Macey PM, Macey KE, Woo MA, Keens TG, Harper RM. Aberrant neural responses to cold pressor challenges in congenital central hypoventilation syndrome. Pediatr Res. 2005;57:500-9. [PubMed: 15718375]

Macey PM, Woo MA, Macey KE, Keens TG, Saeed MM, Alger JR, Harper RM. Hypoxia reveals posterior thalamic, cerebellar, midbrain, and limbic deficits in congenital central hypoventilation syndrome. J Appl Physiol. 2005;98:958-69. [PubMed: 15531561]

Marazita ML, Maher BS, Cooper ME, Silvestri JM, Huffman AD, Smok-Pearsall SM, Kowal MH, Weese-Mayer DE. Genetic segregation analysis of autonomic nervous system dysfunction in families of probands with idiopathic congenital central hypoventilation syndrome. Am J Med Genet. 2001;100:229-36. [PubMed: 11343309] 
Matera I, Bachetti T, Puppo F, Di Duca M, Morandi F, Casiraghi GM, Cilio MR, Hennekam R, Hofstra R, Schober JG, Ravazzolo R, Ottonello G, Ceccherini I. PHOX2B mutations and polyalanine expansions correlate with the severity of the respiratory phenotype and associated symptoms in both congenital and late onset Central Hypoventilation syndrome. J Med Genet. 2004;41:373-80. [PubMed: 15121777]

O'Brien LM, Holbrook CR, Vanderlaan M, Amiel J, Gozal D. Autonomic function in children with congenital central hypoventilation syndrome and their families. Chest. 2005;128:2478-84. [PubMed: 16236912]

Ogawa T, Kojo M, Fukushima N, Sonoda H, Goto K, Ishiwa S, Ishiguro M. Cardio-respiratory control in an infant with Ondine's curse: a multivariate autoregressive modelling approach. J Auton Nerv Syst. 1993;42:41-52. [PubMed: 8436805]

Pattyn A, Morin X, Cremer H, Goridis C, Brunet JF. Expression and interactions of the two closely related homeobox genes Phox2a and Phox2b during neurogenesis. Development. 1997;124:4065-75. [PubMed: 9374403]

Pattyn A, Morin X, Cremer H, Goridis C, Brunet JF. The homeobox gene Phox $2 b$ is essential for the development of autonomic neural crest derivatives. Nature. 1999;399:366-70. [PubMed: 10360575]

Pine DS, Weese-Mayer DE, Silvestri JM, Davies M, Whitaker AH, Klein DF. Anxiety and congenital central hypoventilation syndrome. Am J Psychiatry. 1994;151:864-70. [PubMed: 8184995]

Rand CM, Weese-Mayer DE, Zhou L, Maher BS, Cooper ME, Marazita ML, Berry-Kravis EM. Sudden infant death syndrome: Case-control frequency differences in paired like homeobox (PHOX) 2B gene. Am J Med Genet A. 2006;140:1687-91. [PubMed: 16830328]

Sakai T, Wakizaka A, Matsuda H, Nirasawa Y, Itoh Y. Point mutation in exon 12 of the receptor tyrosine kinase proto-oncogene RET in Ondine-Hirschsprung syndrome. Pediatrics. 1998;101:924-6. [PubMed: 9565426]

Sakai T, Wakizaka A, Nirasawa Y. Congenital central hypoventilation syndrome associated with Hirschsprung's disease: mutation analysis of the RET and endothelin-signaling pathways. Eur J Pediatr Surg. 2001;11:335-7. [PubMed: 11719874]

Sasaki A, Kanai M, Kijima K, Akaba K, Hashimoto M, Hasegawa H, Otaki S, Koizumi T, Kusuda S, Ogawa Y, Tuchiya K, Yamamoto W, Nakamura T, Hayasaka K. Molecular analysis of congenital central hypoventilation syndrome. Hum Genet. 2003;114:22-6. [PubMed: 14566559]

Shaul DB, Danielson PD, McComb JG, Keens TG. Thoracoscopic placement of phrenic nerve electrodes for diaphragmatic pacing in children. J Pediatr Surg. 2002;37:974-8. [PubMed: 12077752]

Silvestri JM, Hanna BD, Volgman AS, Jones PJ, Barnes SD, Weese-Mayer DE. Cardiac rhythm disturbances among children with idiopathic congenital central hypoventilation syndrome. Pediatr Pulmonol. 2000;29:351-8. [PubMed: 10790246]

Silvestri JM, Weese-Mayer DE, Flanagan EA. Congenital central hypoventilation syndrome: cardiorespiratory responses to moderate exercise, simulating daily activity. Pediatr Pulmonol. 1995;20:89-93. [PubMed: 8570308]

Stromme P, Mangelsdorf ME, Shaw MA, Lower KM, Lewis SM, Bruyere H, Lutcherath V, Gedeon AK, Wallace RH, Scheffer IE, Turner G, Partington M, Frints SG, Fryns JP, Sutherland GR, Mulley JC, Gecz J. Mutations in the human ortholog of Aristaless cause X-linked mental retardation and epilepsy. Nat Genet. 2002;30:441-5. [PubMed: 11889467]

Sugar O. In search of Ondine's Curse. JAMA. 1978;240:236-7. [PubMed: 351225]

Todd ES, Scott NM, Weese-Mayer DE, Weinberg SM, Berry-Kravis EM, Silvestri JM, Kenny AS, Hauptman SA, Zhou L, Marazita ML. Characterization of dermatoglyphics in PHOX2B-confirmed congenital central hypoventilation syndrome. Pediatrics. 2006;118:e408-14. [PubMed: 16882781]

Todd ES, Weinberg SM, Berry-Kravis EM, Silvestri JM, Kenny AS, Rand CM, Zhou L, Maher BS, Marazita ML, Weese-Mayer DE. Facial phenotype in children and young adults with PHOX2Bdetermined congenital central hypoventilation syndrome: quantitative pattern of dysmorphology. Pediatr Res. 2006;59:39-45. [PubMed: 16327002]

Toyota T, Yoshitsugu K, Ebihara M, Yamada K, Ohba H, Fukasawa M, Minabe Y, Nakamura K, Sekine Y, Takei N, Suzuki K, Itokawa M, Meerabux JM, Iwayama-Shigeno Y, Tomaru Y, Shimizu H, 
Hattori E, Mori N, Yoshikawa T. Association between schizophrenia with ocular misalignment and polyalanine length variation in PMX2B. Hum Mol Genet. 2004;13:551-61. [PubMed: 14709596]

Trang H, Boureghda S, Denjoy I, Alia M, Kabaker M. 24-hour BP in children with congenital central hypoventilation syndrome. Chest. 2003;124:1393-9. [PubMed: 14555571]

Trang H, Dehan M, Beaufils F, Zaccaria I, Amiel J, Gaultier C. The French Congenital Central Hypoventilation Syndrome Registry: general data, phenotype, and genotype. Chest. 2005;127:72-9. [PubMed: 15653965]

Trang H, Girard A, Laude D, Elghozi JL. Short-term blood pressure and heart rate variability in congenital central hypoventilation syndrome (Ondine's curse). Clin Sci (Lond). 2005;108:225-30. [PubMed: 15544572]

Trang H, Laudier B, Trochet D, Munnich A, Lyonnet S, Gaultier C, Amiel J. PHOX2B gene mutation in a patient with late-onset central hypoventilation. Pediatr Pulmonol. 2004;38:349-51. [PubMed: 15334515]

Trochet D, O'Brien LM, Gozal D, Trang H, Nordenskjold A, Laudier B, Svensson PJ, Uhrig S, Cole T, Niemann S, Munnich A, Gaultier C, Lyonnet S, Amiel J. PHOX2B genotype allows for prediction of tumor risk in congenital central hypoventilation syndrome. Am J Hum Genet. 2005;76:421-6. [PubMed: 15657873]

Trochet D, Hong SJ, Lim JK, Brunet JF, Munnich A, Kim KS, Lyonnet S, Goridis C, Amiel J. Molecular consequences of PHOX2B missense, frameshift and alanine expansion mutations leading to autonomic dysfunction. Hum Mol Genet. 2005;14:3697-708. [PubMed: 16249188]

Utsch B, Becker K, Brock D, Lentze MJ, Bidlingmaier F, Ludwig M. A novel stable polyalanine [poly (A)] expansion in the HOXA13 gene associated with hand-foot-genital syndrome: proper function of poly(A)-harbouring transcription factors depends on a critical repeat length? Hum Genet. 2002;110:488-94. [PubMed: 12073020]

van Limpt V, Schramm A, van Lakeman A, Sluis P, Chan A, van Noesel M, Baas F, Caron H, Eggert A, Versteeg R. The Phox2B homeobox gene is mutated in sporadic neuroblastomas. Oncogene. 2004;23:9280-8. [PubMed: 15516980]

Weese-Mayer DE, Berry-Kravis EM, Marazita ML. In pursuit (and discovery) of a genetic basis for congenital central hypoventilation syndrome. Respir Physiol Neurobiol. 2005;149:73-82. [PubMed: 16054879]

Weese-Mayer DE, Berry-Kravis EM, Zhou L. Adult identified with CCHS-mutation in PHOX2b gene and late onset CHS. Am J Respir Crit Care Med. 2005;171:88. [PubMed: 15615891]

Weese-Mayer DE, Bolk S, Silvestri JM, Chakravarti A. Idiopathic congenital central hypoventilation syndrome: evaluation of brain-derived neurotrophic factor genomic DNA sequence variation. Am J Med Genet. 2002;107:306-10. [PubMed: 11840487]

Weese-Mayer DE, Koch H, Ramirez JM, van Drongelen W, Kenny AS, Hayes ME, Silvestri JM. Breathto-breath variability in idiopathic congenital central hypoventilation syndrome. Am J Respir Crit Care Med. 2003;167:A676. [PubMed: 11343310]

Weese-Mayer DE, Shannon DC, Keens TG, Silvestri JM. American Thoracic Society Statement. Idiopathic congenital central hypoventilation syndrome. Diagnosis and management. Am J Respir Crit Care Med. 1999;160:368-73. [PubMed: 11343310]

Weese-Mayer DE, Silvestri JM, Huffman AD, Smok-Pearsall SM, Kowal MH, Maher BS, Cooper ME, Marazita ML. Case/control family study of autonomic nervous system dysfunction in idiopathic congenital central hypoventilation syndrome. Am J Med Genet. 2001;100:237-45. [PubMed: 11343310]

Weese-Mayer DE, Silvestri JM, Kenny AS, Ilbawi MN, Hauptman SA, Lipton JW, Talonen PP, Garcia HG, Watt JW, Exner G, Baer GA, Elefteriades JA, Peruzzi WT, Alex CG, Harlid R, Vincken W, Davis GM, Decramer M, Kuenzle C, Saeterhaug A, Schober JG. Diaphragm pacing with a quadripolar phrenic nerve electrode: an international study. Pacing Clin Electrophysiol. 1996;19:1311-9. [PubMed: 8880794]

Weese-Mayer DE, Silvestri JM, Marazita ML, Hoo JJ. Congenital central hypoventilation syndrome: inheritance and relation to sudden infant death syndrome. Am J Med Genet. 1993;47:360-7. [PubMed: 8135282] 
Weese-Mayer DE, Silvestri JM, Menzies LJ, Morrow-Kenny AS, Hunt CE, Hauptman SA. Congenital central hypoventilation syndrome: diagnosis, management, and long-term outcome in thirty-two children. J Pediatr. 1992;120:381-7. [PubMed: 1538284]

Weese-Mayer DE, Berry-Kravis EM, Zhou L, Maher BS, Silvestri JM, Curran ME, Marazita ML. Idiopathic congenital central hypoventilation syndrome: analysis of genes pertinent to early autonomic nervous system embryologic development and identification of mutations in PHOX2b. Am J Med Genet. 2003;123A:267-78. [PubMed: 14608649]

Woo MA, Macey PM, Macey KE, Keens TG, Woo MS, Harper RK, Harper RM. FMRI responses to hyperoxia in congenital central hypoventilation syndrome. Pediatr Res. 2005;57:510-8. [PubMed: 15718370]

Woo MS, Woo MA, Gozal D, Jansen MT, Keens TG, Harper RM. Heart rate variability in congenital central hypoventilation syndrome. Pediatr Res. 1992;31:291-6. [PubMed: 1561018]

Young HM, Ciampoli D, Hsuan J, Canty AJ. Expression of Ret-, p75(NTR)-, Phox2a-, Phox2b-, and tyrosine hydroxylase-immunoreactivity by undifferentiated neural crest-derived cells and different classes of enteric neurons in the embryonic mouse gut. Dev Dyn. 1999;216:137-52. [PubMed: 10536054]

\section{Suggested Reading}

Mellins RB, Balfour HH Jr, Turino GM, Winters RW. Failure of automatic control of ventilation (Ondine's curse). Report of an infant born with this syndrome and review of the literature. Medicine (Baltimore). 1970;49:487-504. [PubMed: 5286083]

Weese-Mayer DE, Berry-Kravis EM, Marazita ML. In pursuit (and discovery) of a genetic basis for congenital central hypoventilation syndrome. Respir Physiol Neurobiol. 2005;149:73-82. [PubMed: 16054879]

\section{Chapter Notes}

\section{Author Notes}

Web site: Rush University Medical Center - Pediatric Respiratory Medicine

Web site: School of Dental Medicine - Genetics

Web sites: Fragile X; Neurological Services

\section{Revision History}

- 22 July 2008 (cd) Revision: Testing Strategy

- 23 February 2007 (me) Comprehensive update posted to live Web site

- 17 December 2004 (me) Comprehensive update posted to live Web site

- 28 January 2004 (me) Review posted to live Web site

- 12 August $2003(\mathrm{~mm})$ Original submission 